\title{
Physical Science Students' Perceptions of Their Chemistry Classroom Environment and the Students' Resultant Attitudes towards Chemistry
}

\author{
Kwaku Darko AMPONSAH (Corresponding author) \\ Department of Science \\ OLA College of Education, Cape Coast, Ghana \\ E-mail: kwadaramp@gmail.com \\ Godwin Kwame ABOAGYE \\ Department of Science Education, College of Education Studies \\ University of Cape Coast, Cape Coast, Ghana \\ Elliot Kossi KUMASSAH \\ Department of Teacher Education, P. O. Box LG 1181 \\ University of Ghana, Legon, Accra, Ghana \\ Alfred MENSAH \\ Department of Natural Science Education \\ North West University, Potchefstroom, South Africa
}

Received: May 9, 2018 Accepted: June 25, 2018 Published: August 1, 2018

doi:10.5296/jse.v8i3.13289 URL: https://doi.org/10.5296/jse.v8i3.13289

\begin{abstract}
This paper investigates physical sciences students' perceptions of classroom environment and their attitude towards chemistry in South African High Schools' in the Ximhungwe circuit of the Bohlabela district in the Mpumalanga province of South Africa. The present paper reports on the research findings on associations between the type of school attended by students and
\end{abstract}




\section{Macrothink}

their perception of their chemistry classroom environment and their attitude towards chemistry, as measured with a standardised test. A sample of $21012^{\text {th }}$ grade physical sciences students from the ten public schools in the circuit was conveniently selected to complete a survey on Chemistry Classroom Environment Questionnaire (CCEQ) and Attitude Towards Chemistry Questionnaire (ATCQ). One-way multivariate analysis of variance (MANOVA) and a follow-up between-group analysis of variance (ANOVA) was conducted and showed that students in high achieving schools (HAS) had a high perception of their CCEQ inventory, which was influenced by all the five sub-scales. Mean scores and independent samples t-tests showed that students in both school types had a positive attitude towards chemistry. Spearman's Correlation revealed that there was no relationship between physical sciences students' perception of their classroom environment and their attitude towards chemistry in both types of schools. The study discusses these findings and compares them to prior learning environment studies.

Keywords: Attitude, chemistry classroom environment, low and high achieving schools, perceptions, physical sciences 


\section{Introduction}

The learning environment in education by and large has an enormous influence on what students learn or achieve at the end of the day. According to Ryan (2013), large amounts of students' time is spent sitting in a learning environment because this place is where they will learn the various skills deemed necessary and proper for them to achieve success in the global society. It serves as the place where they will gain an understanding of their place in the world and the gifts that they have to offer it.

Ryan (2013) has opined that the learning environment is where the students develop ideas about how they want their future to look, as well as knowledge of the skills needed to reach that goal. Ryan indicated that the learning environment is an essential place in the academic growth of students, and it is expedient to understand the ways in which it affects achievement in order to maximize effectiveness in instruction (Ryan, 2013). Other research has also given vivid description of the classroom environment. For instance, Bates (2014) has posited that the learning environment refers to the diverse physical locations, contexts, and cultures in which students learn. Bates further indicated that the term includes the culture of a school or class, its presiding tenet and characteristics, including how individuals interact with and treat one another as well as the ways in which teachers may organize an educational setting to facilitate learning. Accordingly, Stewart, Evans and Kaczynski (as cited in Turano, 2005), indicated that the learning environment cannot be isolated as one specific entity, as the whole environment of the learning platform consists of several factors such as physical learning environment, social learning environment (teacher effectiveness, behaviour management and instructional time management) and the psychological, emotional, or psychosocial learning environment. To Turano (2005), the factors that contribute to learning environment are relevant to students of all ages and grade levels and all learning environments have climates that could play a serious role in the success of the students.

Further research on the concept of classroom environment as applied to educational setting is viewed as a place where students and teachers interact with each other and use a variety of tools and resources in their pursuit of learning activities (Bucholz \& Sheffler, 2009; Mucherah, 2008). Accordingly, Fraser (1982), Husain, Mustapha, Malik, and Mokhtar (2014), and Maat, Adnan, Abdullah, Ahmad, and Puteh (2015) have observed that classrooms are specific places in schools where results of education, that is, understanding and application of knowledge in our lives, are expected to be achieved, and these places have considerable influence on students in respect of achieving these noble goals. Thus, creating favourable classroom environments should be of great importance to science educators as evidenced from empirical studies.

Evidence emerging from empirical studies also indicates that students' learning and achievement are also influenced by their classroom environments. Students spend quality time at school with their teachers as compared to their parents at home. Accordingly, the influence of the teacher on learner achievement cannot be overemphasized. Consequently, research has shown that a positive teacher-student relationship has the potential of improving student achievement (Wubbles, Breklmans, \& Hermans, 1987). Wubbles et al 


\section{Macrothink}

(1987), and Mandina and Mambanda (2012) have suggested that teacher-student interaction is a powerful force that canplay amajor role in influencing cognitive and affective development of students. Çakir (2011) reaffirmed the role and significance of teacher behaviourin classroomenvironment and in particular how this can influence students' motivation leading to achievement. These researchers indicated that improvement can be made based on the feedback and evaluation towards the learning environment.

\section{Theoretical Framework}

\subsection{The What Is Happening In this Class (WIHIC) Questionnaire}

The WIHIC measures high school students' perceptions of their classroom environment (Fraser, Fisher, \& McRobbie, 1996) and a wide range of dimensions that are important to the current situation in classrooms. The WIHIC includes relevant dimensions from past questionnaires and combines these with dimensions that measure particular aspects of constructivism and other relevant factors operating in contemporary classrooms. A description of each scale in the WIHIC is presented in Table 1. Moos' (1979) conceptual framework for human environments that characterizes environments as having relationship, personal growth, and system maintenance and change dimensions have also been included in Table 1. According to Dorman (2003), Moos explained that relationship dimensions are concerned with the nature and intensity of personal relationships, and personal growth dimensions focus on opportunities for personal development and self-enhancement. System maintenance and system change dimensions assess the extent to which the environment is orderly, clear in expectations, maintains control, and is responsive to change. 
Table 1. Scale Description for each Scale and Example of Items in the What Is Happening in This Class? (WIHIC) Questionnaire

\begin{tabular}{|c|c|c|c|}
\hline Scale & Description & Item & $\begin{array}{l}\text { Moos' } \\
\text { Dimension }\end{array}$ \\
\hline Student & Extent to which students & I make friendship & Relationship \\
\hline Cohesiveness & $\begin{array}{l}\text { know, help and are supportive } \\
\text { of one another. }\end{array}$ & $\begin{array}{l}\text { among students in } \\
\text { this class. }\end{array}$ & \\
\hline Teacher support & $\begin{array}{l}\text { Extent to which teacher } \\
\text { helps, befriends, trusts, and } \\
\text { shows interest in students. }\end{array}$ & $\begin{array}{l}\text { The teacher takes a } \\
\text { personal interest in } \\
\text { me. }\end{array}$ & Relationship \\
\hline Involvement & $\begin{array}{l}\text { Extent to which students have } \\
\text { attentive interest, participate } \\
\text { in discussions, perform } \\
\text { additional work and enjoy the } \\
\text { class. }\end{array}$ & $\begin{array}{l}\text { I discuss ideas in } \\
\text { class. }\end{array}$ & Relationship \\
\hline Investigation & $\begin{array}{l}\text { Extent to which there is } \\
\text { emphasis on the skills } \\
\text { and their use in } \\
\text { problem-solving } \\
\text { investigation. }\end{array}$ & $\begin{array}{l}\text { I am asked to think } \\
\text { about the evidence } \\
\text { for statements. }\end{array}$ & $\begin{array}{l}\text { Personal } \\
\text { growth }\end{array}$ \\
\hline Task Orientation & $\begin{array}{l}\text { Extent to which it is } \\
\text { important to complete } \\
\text { activities planned and to stay } \\
\text { on the subject matter. }\end{array}$ & $\begin{array}{l}\text { Getting acertain } \\
\text { amount of work } \\
\text { done is important. }\end{array}$ & $\begin{array}{l}\text { Personal } \\
\text { growth }\end{array}$ \\
\hline Cooperation & $\begin{array}{l}\text { Extent to which students } \\
\text { cooperate rather than } \\
\text { compete with one } \\
\text { another on learning tasks. }\end{array}$ & $\begin{array}{l}\text { I cooperate with } \\
\text { other students when } \\
\text { doing assignment } \\
\text { work. }\end{array}$ & $\begin{array}{l}\text { Personal } \\
\text { growth }\end{array}$ \\
\hline Equity & $\begin{array}{l}\text { Extent to which the teacher } \\
\text { treats students equally. }\end{array}$ & $\begin{array}{l}\text { The teacher gives as } \\
\text { much attention to my } \\
\text { questions as to other } \\
\text { students' questions. }\end{array}$ & $\begin{array}{l}\text { System } \\
\text { maintenance } \\
\text { and change }\end{array}$ \\
\hline
\end{tabular}

The original version of the WIHIC contained 90 items and nine scales but was refined by both statistical analysis and extensive interviewing of students to the current 40 items and 8 scales (Fraser et al., 1996; Huang \& Fraser, 1997). The WIHIC has been reported as useful and valid across a number of countries and subjects (Den Brok, Fisher, Rickards, \& Bull, 2006, pp. 7-8). Dorman (2003) reported that the reliability of the scales (Cronbach's alpha) of the WIHIC instrument is usually above .70 at the student level and above .85 at the class level. Exploratory and confirmatory factor analysis indicates that the items of the WIHIC usually have factor loadings above .40 on their a priori scales and lower loadings on other scales. Average correlations between the scales of the WIHIC, a convenient measure of discriminate validity, have been reported between approximately .20 and .50 , indicating that 
each of the seven scales measures distinct, though partly overlapping, elements of the classroom environment (Fraser, 1998).

\section{Statement of the Problem}

The Department of Basic Education in South Africa has placed strong emphasis on science education in its educational system over the years through various governmental programmes, such as winter schools, spring schools, and special weekend camps, with much focus in the rural areas (Department of Basic Education Mpumalanga Province [DBEMP], 2015). In spite of this, the majority of grade 12 students still perform poorly, especially in the Bohlabela District of the Mpumalanga Province in the final National Senior Certificate (NSC) examinations to the extent that it is very difficult for some students to get $30 \%$, the pass mark in South African High Schools (DBEMP, 2015). In addition, most classroom environment studies have been carried out in developed countries and very little has been reported on how high school science students perceive their chemistry classroom environment and their resultant attitude towards the subject in Africa.

However, some high schools in the rural area still perform better than others. This is surprising because these students originated from the same rural community and have common backgrounds. These observed differences called for an investigation into the chemistry classroom environment to ascertain the discrepancy. This paper therefore reports a study of students' perceptions of classroom environment and their resultant attitude towards chemistry in a rural setting in South Africa.

\section{The Purpose of the Study}

Based on the problems highlighted, the study aimed at investigating the following:

i) Physical sciences students' perception of their chemistry classroom environment and attitude towards chemistry.

ii) Association between physical sciences students' perception of their chemistry classroom environment and their attitude towards chemistry.

\section{Research Hypothesis}

The following null hypotheses were tested at $\mathrm{P} \leq .05$ and were formulated to guide the study.

1. There is no statistically significant difference between physical sciences students' perception of their chemistry classroom environment in LAS and HAS.

2. There is no statistically significant difference between physical sciences students' attitude towards chemistry in LAS and HAS.

3. There is no statistically significant association between physical sciences students' perception of their classroom environment and their attitude towards chemistry in both types of schools. 


\section{Significance of the Study}

The study is significant for a number of reasons. Results of the study had provided additional information regarding factors that influence the perception of students of their chemistry classroom environment and their attitude towards chemistry. Guidance coordinators as well as teachers in schools could use the recommendations to support students in their studies. The outcome of the study would help educational policy formulators, implementers and curriculum developers to adopt appropriate strategies that will help improve the performance of students in physical sciences. The study has also shed some light on possible reasons why some students perform poorly in specific chemistry classroom environments. It has also highlighted issues relating to positive attitudes of students towards chemistry. It is hoped that teachers will use it to improve the teaching of chemistry in their classrooms.

\subsection{Scope and delimitation of the study}

There are sixteen circuits in the Bohlabela District in the Mpumalanga province. But the study confined itself to the Ximhungwe circuit because of its proximity to the researcher and the fact that it is one of the low-performing circuits. The study also restricted itself to only physical sciences students because the researcher wanted to look at the chemistry classroom environment. Only grade 12 students were used as respondents because they have had three years of physical science education and would have had some experience needed to respond to the statements in the questionnaire.

\section{Research Methodology and Procedure}

\subsection{Research Design}

A cross-sectional survey was used in carrying out the study. This design was used in order to test the three hypotheses formulated to guide the study. The design made it possible for comparison to be made between the two different groups of students in terms of performance (Awang, 2014). To accomplish this, the ten high schools in the Ximhungwe circuit of the Bohlabela District in the 2015 academic year were categorized into low achieving schools (LAS) and high achieving schools (HAS) based on the individual school's achievement in the National Senior Certificate (NSC) examinations from 2008 to 2014 (DBEMP, 2015). All the schools have one intact physical science class.

\subsection{Population of the study}

The target population for the study comprised all the 210 grade 12 physical sciences students from the 10 high schools in the Ximhungwe circuit in the 2015 academic year. All the schools were co-educational and were located in a rural setting. The categorisation of the schools in this study was based on the general performance of the schools as well as their performance specifically in physical sciences as prescribed by the Department of Basic Education (DBE) (DBEMP, 2015). 


\subsection{Sample and Sample Technique}

All 210 physical science students from the ten schools formed the sample and participated in the study. The schools were selected by means of convenient sampling. Ninety-eight students comprising $57.1 \%$ females and $42.9 \%$ males with a mean age 17.8 year and a standard deviation of 0.92 years were from HAS. In the LAS, there were 112 students comprising $46.4 \%$ females and $53.6 \%$ males with a mean age of 18.8 years and a standard deviation of 1.66 years.

\subsection{Research Instrument}

\subsubsection{Development and Validation of the Questionnaire}

Chemistry Classroom Environment Questionnaire (CCEQ) and Attitudes Towards Chemistry Questionnaire (ATCQ) were the main instruments used for data collection. In constructing the CCEQ, "What Is Happening in This Class?" (WIHIC) instrument developed by Fraser et al (1996) to measure high school students' perception of their science classroom environment was adopted for the study. However, it was assumed that the five sub-scales of student cohesiveness, teacher support, involvement, cooperation, and equity out of the seven sub-scales in the original WIHIC would be evident in chemistry classrooms in South Africa (Refer to Table 1). The CCEQ and ATCQ questionnaires that were constructed for this study were validated by experts in the Institute for Science and Technology and Education (ISTE) of the University of South Africa in the area of classroom environment and attitudes to assess face and content validity. These questionnaires were also made available to teachers in the schools where they were pilot-tested for their comments to ensure that students were not confused with any of the statements. The reliabilities recorded for each sub-scale under the Chemistry Classroom Environment Questionnaire confirmed that the sub-scale constructs existed in the chemistry classrooms.

The Attitude Towards Chemistry Questionnaire was constructed by adopting the Test of Science Related Attitude (TOSRA) developed by Fraser (1982) as a guide. The TOSRA was used because it has been used in a number of cross-national studies to measure secondary school students' attitudes to science and it has recorded acceptable reliabilities in all of these investigations. In developing the ATCQ it was assumed that attitude towards chemistry was one-dimensional and since the items on the original TOSRA did not reflect the South African context, 12 items were written under the attitude one-dimensional instrument. They were then subjected to inter-item correlation coefficient analyses and reported inter-item correlation coefficients of above 0.30 making they suitable for the study in South Africa.

\subsection{Method of Data Collection}

The CCEQ and ATCQ were administered by the researcher to students in all the schools that participated in the study. This was done in the third week of January, which was the $1^{\text {st }}$ term of the 2015 academic year after seeking permission from the Department of Basic Education, Mpumalanga Province (DBEMP) and the principals of the schools that participated in the study in the last quarter of the 2014 academic year. The principals of the high schools that were used in the study were first written to and then visited to establish rapport and to make 
arrangements with the physical sciences teachers and students before the actual date for data collection. Data were then collected by the researcher by moving from one school to another. The data collection was done within three weeks, after normal classes, one school per day, excluding Fridays and weekends. In each school the students were given the CCEQ and then the ATCQ to complete.

They were administered to the students in all the ten schools involved in the study in English, which is the main medium of instruction in South African high schools. The instructions on the instruments were read out to the students and confidentiality of their responses was assured before they were allowed to read the items on their own. The researcher was also available when the instrument was being completed to ensure high return rate, and also to ensure all items on the instrument were completed. The completed instruments were collected the same day. Teachers whose classes were involved in the study were asked to excuse the students, since their presence during the completion of the instruments could influence the students' responses to the items. It took an average of thirty minutes for the students in a class to complete the instrument.

\subsection{Analysis of Data}

Responses to test the differences in physical sciences students' perception of their chemistry classroom environment in LAS and HAS were obtained from grade 12 physical sciences students in the different school types using the CCEQ. The items on the CCEQ were assigned values on a five-point Likert-type scale format. The mean and standard deviation scores for each dimension of the CCEQ were estimated, and physical science students' perception of their chemistry classroom environment was measured. One-way multivariate analysis of variance (MANOVA) was conducted to determine the differences in physical science students' perception of their chemistry classroom environment in both school types with the five-chemistry classroom environment sub-scales as the dependent variable and the school type as the independent variable. A corresponding one-way analysis of variance (ANOVA) with school type as the independent variable was conducted for each of the sub-scales of CCEQ individually as a follow-up test to the MANOVA to determine where the significant differences that existed between the school categories.

Similarly, the ATCQ was used to obtain information to test the differences in physical sciences students' attitude towards chemistry in both LAS and HAS. The items on the ATCQ were assigned values on a five-point Likert-type scale format. Mean and standard deviation scores of the responses on the attitude instrument for both school types were calculated. Independent samples t-tests were also conducted on the items in the attitude instrument to determine those that showed significant differences between the students in both school types.

\section{Results and Discussions}

\subsection{Physical Sciences Students' Perception of their Chemistry Classroom Environment}

$\mathrm{H}_{\mathrm{o} 1}$ : The first hypothesis states that there is no significant difference in physical sciences students' perception of their chemistry classroom environment in both school types. The 
students' perceptions of their chemistry classroom environment across the five sub-scales were analysed using mean and standard deviation scores obtained from their responses and presented in Table 2.

Table 2. Mean (M) and Standard Deviation (SD) Responses for LAS and HAS on Chemistry Classroom Environment (CCE) Sub-scales

\begin{tabular}{lllll}
\hline CCE Sub-Scale & \multicolumn{3}{c}{ School Type } \\
\cline { 2 - 5 } & Mean & SD & Mean & SD \\
\hline Student Cohesiveness [SC] & 3.78 & 0.57 & 4.32 & 0.41 \\
Teacher Support [TS] & 3.49 & 0.94 & 4.40 & 0.71 \\
Involvement [IV] & 3.47 & 0.70 & 4.06 & 0.58 \\
Cooperation [CO] & 3.63 & 0.68 & 4.35 & 0.97 \\
Equity [EQ] & 3.79 & 0.88 & 4.28 & 0.66 \\
\hline
\end{tabular}

$N=112$ (LAS) = low achieving schools; $N=98$ (HAS) =high achieving schools.

Table 2 indicates that physical science students in both school types had a high perception of their chemistry classroom environment but in favour of HAS. For further analysis, one-way Multivariate Analysis of Variance (MANOVA) was used to determine the sub-scale(s) that contributed to the differences between the physical science students' perception of their chemistry classroom environment both within and between school types. The results are presented in Table 3.

Table 3. One-way MANOVA on CCE scales and type of school

\begin{tabular}{llllll}
\hline Effect & Value & $\mathrm{F}$ & $\begin{array}{l}\text { Hypothesis } \\
\mathrm{df}\end{array}$ & $\begin{array}{l}\text { Error } \\
\mathrm{df}\end{array}$ & $\begin{array}{l}\mathrm{p}- \\
\text { values }\end{array}$ \\
\hline Category of school & 0.66 & 10.42 & 5.00 & 204.00 & 0.000 \\
\hline
\end{tabular}

Significant $\mathrm{p}<.05$

The MANOVA test presented in Table 3 showed that Wilks' lambda $(\lambda)$ value of 0.66 was statistically significant, $F(5,210)=10.42, p<0.05$; partial eta squared $=0.345$, indicating that the population mean scores on the five sub-scales of chemistry classroom environment are the same for the two types of schools and the hypothesis cannot be supported and was therefore rejected. This means that there is a statistically significant difference between the perceptions of physical science students in both types of schools across the five sub-scales of their chemistry classroom environment.

As a follow-up test to the MANOVA, the results of one-way ANOVA with school type as the independent variable was conducted for each of the five sub-scales of chemistry classroom environment as shown in Table 4. As shown in Table 4, all sub-scales of chemistry classroom environment were statistically significant using a Bonferroni adjusted alpha level of 0.05: student cohesiveness: $F(2,210)=6.6, p=0.002$, partial eta squared $=0.036$; teacher support: $F$ 
$(2,210)=6.6, p=0.002$, partial eta squared $=0.036$; involvement: $F(2,210)=6.6, p=0.002$, partial eta squared $=0.036$; cooperation $\mathrm{F}(2,210)=27.88, \mathrm{p}<0.001$, partial eta square $=0.14$; and equity: $\mathrm{F}(2,210)=8.39, \mathrm{p}<0.001$; partial eta squared $=0.05$.

Table 4. Results of ANOVA as a follow up to the one -way MANOVA on the five sub-scales of chemistry classroom environment

\begin{tabular}{llllll}
\hline CCE Sub-Scales & df & $\begin{array}{l}\text { Mean } \\
\text { Squared }\end{array}$ & F & $\begin{array}{l}\text { p- } \\
\text { values }\end{array}$ & $\begin{array}{l}\text { Partial } \\
\text { Eta Squared }\end{array}$ \\
\hline Student Cohesiveness & 1 & 488.6 & 30.5 & $0.000^{*}$ & 0.228 \\
Teacher support & 1 & 1391.1 & 30.5 & $0.000^{*}$ & 0.229 \\
Involvement & 1 & 578.3 & 21.8 & $0.000^{*}$ & 0.175 \\
Cooperation & 1 & 866.3 & 19.8 & $0.000^{*}$ & 0.161 \\
Equity & 1 & 413.9 & 10.5 & $0.002^{*}$ & 0.093 \\
\hline
\end{tabular}

*Bonferroni Adjusted significant at $\mathrm{P}<0.05$.

The partial eta squared values recorded for the five sub-scales indicate that all the five sub-scales account for the variances in physical science students' perception of their chemistry classroom environment in low and high achieving schools. An inspection of the mean scores as presented in Table 2indicated that physical science students in high achieving schools had slightly higher means for all the five sub-scales than physical sciences students in low achieving schools.

The analysis conducted on the first hypothesis has shown that physical science students in both HAS and LAS had a high perception of their chemistry classroom environment but in favour of physical science students in high achieving schools. This result confirms what Riah (2003), Chui-Seng (2004) and Mucherah (2008) found in their study with science students in Taiwan, Brunei, and Kenya respectively. Riah (2003), Chui-Seng (2004) and Mucherah (2008) reported that science students in these countries had a high perception across all the sub-subscales except the involvement sub-scale of their biology classrooms. However, students in the current study had a high perception of their chemistry classroom across all the subscales including the involvement sub-scale. There is one known study using the WIHIC carried out in South Africa. Aldridge et al (2004) compared students' perceptions on the WIHIC between South Africa and Australia. Their study showed that students in South Africa perceived a greater degree of investigation opportunities in their science classrooms than Australian students, while students perceived less cooperation and equity in South Africa than students in Australia. This result is surprising since laboratories are non-existent in most rural high schools in South Africa. In the Ximhungwe circuit for instance only three out of the ten high schools have science laboratories, which unfortunately are not very functional. This current study also contradicts what Otami et al (2012) found in their study with elective science students in Ghana, which indicated a low perception of their biology classroom on all the sub-scales. 
8.2 Physical sciences Students’ Attitude towards Chemistry

$\mathrm{H}_{\mathrm{o} 2}$ : The second hypothesis sought to test the differences in attitude towards chemistry between physical sciences students in both low and high achieving schools. This was done by considering attitude towards chemistry as one-dimensional. The results are presented in Table 5. Attitude of physical science students towards chemistry was analysed using the mean and standard deviation scores of responses provided by the students. Negative statements were reversed to ensure that their mean scores corresponded to that of the positive statements. Physical sciences students in both school types had mean scores greater than the average mean score of three (Table 5). These results suggest that physical science students in both school types have a positive attitude towards chemistry but slightly in favour of students in high achieving schools. 


\section{Mll Macrothink}

Journal of Studies in Education

ISSN 2162-6952

2018, Vol. 8, No. 3

Table 5. Mean (M) and Standard Deviation (SD) scores of items constituting attitude towards Chemistry in LAS and HAS

\begin{tabular}{|c|c|c|c|c|c|c|}
\hline No. & Statements & $\begin{array}{l}\text { School } \\
\text { Type }\end{array}$ & M & $\mathrm{SD}$ & $\mathrm{t}$ & $\mathrm{P}$ \\
\hline 1 & $\begin{array}{l}\text { It is best to find out why } \\
\text { something is true by checking } \\
\text { it from Chemistry textbooks } \\
\text { than being told. }\end{array}$ & $\begin{array}{l}\text { LAS } \\
\text { HAS }\end{array}$ & $\begin{array}{l}4.38 \\
4.10\end{array}$ & $\begin{array}{l}0.926 \\
1.141\end{array}$ & $\begin{array}{l}1.353 \\
1.334\end{array}$ & 0.691 \\
\hline 2 & $\begin{array}{l}\text { The topics covered in } \\
\text { Chemistry are not interesting. }\end{array}$ & $\begin{array}{l}\text { LAS } \\
\text { HAS }\end{array}$ & $\begin{array}{l}1.96 \\
1.67\end{array}$ & $\begin{array}{l}1.144 \\
1.068\end{array}$ & $\begin{array}{l}1.340 \\
1.347\end{array}$ & 0.794 \\
\hline 3 & $\begin{array}{l}\text { There should be more } \\
\text { Chemistry lessons every } \\
\text { week. }\end{array}$ & $\begin{array}{l}\text { LAS } \\
\text { HAS }\end{array}$ & $\begin{array}{l}4.41 \\
4.59\end{array}$ & $\begin{array}{l}1.092 \\
0.762\end{array}$ & $\begin{array}{l}-0.972 \\
-0.995\end{array}$ & 0.064 \\
\hline 4 & $\begin{array}{l}\text { Chemistry is one of the most } \\
\text { interesting science subjects }\end{array}$ & $\begin{array}{l}\text { LAS } \\
\text { HAS }\end{array}$ & $\begin{array}{l}4.30 \\
4.78\end{array}$ & $\begin{array}{l}1.077 \\
0.422\end{array}$ & $\begin{array}{l}-2.878 \\
-3.024\end{array}$ & $0.000 *$ \\
\hline 5 & $\begin{array}{l}\text { I am always prepared for } \\
\text { chemistry lessons. }\end{array}$ & $\begin{array}{l}\text { LAS } \\
\text { HAS }\end{array}$ & $\begin{array}{l}4.04 \\
4.41\end{array}$ & $\begin{array}{l}0.990 \\
0.814\end{array}$ & $\begin{array}{l}-2.087 \\
-2.114\end{array}$ & 0.916 \\
\hline 6 & Chemistry lessons are boring. & $\begin{array}{l}\text { LAS } \\
\text { HAS }\end{array}$ & $\begin{array}{l}1.43 \\
1.33\end{array}$ & $\begin{array}{l}0.828 \\
0.875\end{array}$ & $\begin{array}{l}0.613 \\
0.611\end{array}$ & 0.585 \\
\hline 7 & $\begin{array}{l}\text { It is important to study } \\
\text { Chemistry at school. }\end{array}$ & $\begin{array}{l}\text { LAS } \\
\text { HAS }\end{array}$ & $\begin{array}{l}4.55 \\
4.33\end{array}$ & $\begin{array}{l}0.685 \\
0.944\end{array}$ & $\begin{array}{l}1.422 \\
1.393\end{array}$ & 0.096 \\
\hline 8 & $\begin{array}{l}\text { I would like to study } \\
\text { Chemistry related courses at } \\
\text { the highest level of my } \\
\text { education. }\end{array}$ & $\begin{array}{l}\text { LAS } \\
\text { HAS }\end{array}$ & $\begin{array}{l}4.11 \\
4.20\end{array}$ & $\begin{array}{l}1.123 \\
0.979\end{array}$ & $\begin{array}{l}-0.468 \\
-0.473\end{array}$ & 0.361 \\
\hline 9 & $\begin{array}{l}\text { Doing well in Chemistry is } \\
\text { important to me. }\end{array}$ & $\begin{array}{l}\text { LAS } \\
\text { HAS }\end{array}$ & $\begin{array}{l}4.70 \\
4.86\end{array}$ & $\begin{array}{l}1.79 \\
1.53\end{array}$ & $\begin{array}{l}-1.640 \\
-1.695\end{array}$ & $0.002 *$ \\
\hline 10 & I enjoy Chemistry lessons. & $\begin{array}{l}\text { LAS } \\
\text { HAS }\end{array}$ & $\begin{array}{l}4.48 \\
4.57\end{array}$ & $\begin{array}{l}0.809 \\
0.791\end{array}$ & $\begin{array}{l}-0.570 \\
-0.571\end{array}$ & 0.611 \\
\hline 11 & $\begin{array}{l}\text { I would enjoy science more if } \\
\text { there were no Chemistry } \\
\text { lessons. }\end{array}$ & $\begin{array}{l}\text { LAS } \\
\text { HAS }\end{array}$ & $\begin{array}{l}2.36 \\
2.39\end{array}$ & $\begin{array}{l}1.420 \\
1.525\end{array}$ & $\begin{array}{l}-0.106 \\
-0.106\end{array}$ & 0.318 \\
\hline 12 & $\begin{array}{l}\text { Chemistry is the most } \\
\text { difficult of all the science } \\
\text { subjects. }\end{array}$ & $\begin{array}{l}\text { LAS } \\
\text { HAS }\end{array}$ & $\begin{array}{l}1.79 \\
1.53\end{array}$ & $\begin{array}{l}1.074 \\
1.063\end{array}$ & $\begin{array}{l}1.220 \\
1.221\end{array}$ & 0.804 \\
\hline
\end{tabular}

*Significant at $\mathrm{p}>0.05 ;$ Degree of freedom $(\mathrm{df})=208$

As a follow-up test, an independent samples t-test, $\underline{\mathrm{t}}(210)=1.96, \mathrm{p}=0.436$ was conducted to determine whether there was a significant difference between students in both low and high achieving schools with regard to their attitude towards chemistry showed that there is no significant difference between the students in both school types. The results from the 
analysis of the second hypothesis are similar to Coleman (2004) who reported that science students in low and high achieving schools in Singapore have a positive attitude towards science.

\subsection{Association between students' attitude toward chemistry and perception of chemistry classroom environment}

$\mathrm{H}_{03}$ : Hypothesis three states that there is no significant association between physical science students' perception of their classroom environment and their attitude towards chemistry in both types of schools. Table 6 shows a simple bivariate association between attitude and perception measures. An examination of simple correlation coefficient (Spearman's rank order correlation coefficient, r) reported in Table 6 shows that there were no statistically significant relationships between attitude and perception measures for students in both HAS and LAS $(\mathrm{r}=0.02, \mathrm{n}=210, \mathrm{p}>0.05)$.

Table 6. Spearman's correlation between students' perception of their chemistry classroom environment and their attitude towards chemistry in LAS and HAS

\begin{tabular}{llll}
\hline CCE Sub-Scales & $\mathrm{N}$ & $\mathrm{r}$ & significance \\
& & & \\
\hline Attitude versus perception (HAS students) & 98 & 0.016 & 0.811 \\
Attitude versus perception (LAS surdents) & 112 & -0.021 & 0.769 \\
\hline
\end{tabular}

*Not significant, $\mathrm{p}>.05$

From the analyses of the third hypothesis, which was to find out if there was any association between physical sciences students' perception of their classroom and their attitude towards chemistry, Spearman's rank order correlation revealed that virtually no relationship exists between physical sciences students' perception of their chemistry classroom environment and their attitude toward chemistry in LAS or HAS. This is surprising because the results are inconsistent with studies by Mucherah (2008) and Myint \& Goh (2001), who reported that classroom environments are perceived by students as being conducive and tend to enhance the development of positive attitude towards a subject matter and hence, better achievement.

\section{Conclusion, implication and recommendation}

\subsection{Conclusion}

The results from the study indicate that physical science students in both low and high achieving schools had high perception of their chemistry classroom environments but significantly in favour of students in high achieving schools. The physical students' perception of their chemistry classroom environment was therefore not influenced by school type. The differences were in all the five sub-scales of student cohesiveness, teacher support, involvement, cooperation, and equity.

Also, students in both low and high achieving schools had a positive attitude towards chemistry. This seems to suggest that physical science students' attitude towards chemistry was not influenced by school type. However, students in high achieving schools had a slightly higher positive attitude towards chemistry than their counterparts in low achieving 
schools even though independent samples t-test indicated that this difference was not significant.

The fact that no relationship was established between physical science students' perception of their chemistry classroom environment and their attitude towards chemistry seem to suggest that one's perception may not necessarily influence one's attitude.

\subsection{Implication}

These findings have several implications for chemistry teaching and practice. Understanding how low and high-achieving students perceive their environment differently can enable teachers to focus their attention on critical areas of teaching and learning. Students learn through applying what they are taught to their own experience and knowledge and then formulating new concepts (Bransford et al. 2001). The highest average mean score for students from high achieving school was teacher support followed by cooperation, which suggests that the teacher influence and peer collaboration might go a long way to help these students to achieve in their chemistry classroom. However, the highest average mean score for students from low achieving schools was cooperation followed by equity, suggesting that both types of students perceive cooperation as a very important classroom environment dimension. Thus, understanding of the influence of teacher interpersonal behaviour as well as cooperation on students' perceptions of classroom environment could help educators to impact positively on their students. In this study high-achieving students were found to be the most positive about their chemistry classroom environment. Thus, if this finding holds true across a larger sample, then it is imperative that teachers employ collaborative approaches in their classroom delivery, which may influence the performance and consequently high perceptions of chemistry classroom environment for both low and high achieving students.

\subsection{Recommendation}

Achievement levels and chemistry experience should be investigated at further depth to understand the broader impact of these factors on student perceptions and ultimately learning. It would be very useful to understand more about what makes certain groups of students more positive about their learning environment than others. Interviewing students who complete the CCEQ and asking them why they perceive, for example, specific scales in the inventory in the way they do could advance the way chemistry classroom environments are structured and the way students learn. Furthermore, observations of classes that report varied perceptions of their learning environments could enhance in-depth understanding of intrinsic differences.

\section{References}

Aldridge, J., Laugksch, R. C., \& Fraser, B. J. (2004, April). A cross-national study of the learningenvironments of science classrooms in South Africa and Australia. A paper presented at the Annual Meeting of the American Educational Research Association, San Diego, CA. April, 2004.

Awang, Z. (2014). Research Methodology and Data Analysis (2nd ed.). Universiti 
Teknologi Mara, UiTM Press.

Bates, A. W. (2014). What is a learning environment? Available at: https://opentextbc.ca/teachinginadigitalage/chapter/5-2-what-is-a-learning-environment/.(Ac cessed 20 March 2018).

Bransford J. D., Brown A. L., \&Cocking R. R., (Eds) (2001). How people learn: Brain, mind, experience, and school. Washington, DC: National Academy Press.

Bucholz, J. L., \& Sheffler, J. L. (2009). Creating a Warm and Inclusive Classroom Environment: Planning for All Children to Feel Welcome, Electronic Journal for Inclusive Education, 2(4), 1-13.

Çakir, M. (2011). Validity and Reliability of the Turkish Form of Technology-Rich Outcome-Focused Learning Environment Inventory. Educational Sciences: Theory \& Practice, 11, 1959-1963.

Chui-Seng, Y.B. (2004). Secondary science students' perceptions of their learning environment and its association with achievement in biology. Learning Environment Research, 7, 134-146.

Coleman, G.H. (2004). A comparative study of students' attitude towards science. International Journal of Science Education, 89(3), 112-128.

DBEMP (2015). Feedback on the 2014 NSC examination and resource material in physical sciences. Mpumalanga Province: Mpumalanga Department of Education.

Den Brok, P., Fisher, D., Rickards, T., \& Bull, E. (2006). Californian science students' perceptions of their classroom learning environments. Educational Research and Evaluation. Page 3 to 25. 2005, April. Fraser, B. J. (1982). Test of science related attitudes (TOSRA). Melbourne, Australia: Australian Council for Educational Research.

Fraser, B.J., McRobbie, C.J., \& Fisher, D.L. (1996). Development, validation and use of personal and class forms of a new classroom environment instrument. Paper presented at the Annual Meeting of the American Education Research Association, Chicago, 13-17.

Fraser, B. J. (1998a). Validity and use of classroom environment instruments. Journal of Classroom Interaction, 26(2), 5-11.

Husain, M. Y., Mustapha, R., Malik, S. A., \& Mokhtar, S. B. (2014). Review of Measurement Item of Engineering Student's Learning Environment: Confirmatory Factor Analysis. Journal of Technical Education and Training, 6, 42-56.

Maat, S. M., Adnan, M., Abdullah, M. F. N. L., Ahmad, C. N. C., \& Puteh, M. (2015). Confirmatory Factor Analysis of Learning Environment Instrument among High-Performance School Students. Creative Education, 6, 640-646. https://doi.org/10.4236/ce.2015.66063

Mandina, S., \& Mambanda, I. (2012). Science Teacher Quality and Effectiveness: Gweru Urban Junior Secondary School Students' Points of View. Asian Social Science, 8(8), 
$160-165$.

Mucherah, W. (2008). Classroom climate and students, goal structure in high school biology classrooms in Kenya. Learning Environment Research, 11, 63-81. https://doi.org/10.1007/s10984-007-9036-X

Otami, D. C., Ampiah, J. G., \& Anthony-Kruger, C. (2012). Factors influencingelective science students' perception of their Biology classroom environment in low and high academic achieving schools in the Central Region of Ghana. International Journal of Research Studies in Education, 1(1) 35-46.

Riah, H (2003). Environment-Attitude associations in the chemistry laboratory classroom. Research in Science and Technological Education, 64, 29-40.

Ryan, H. (2013). The Effect of Classroom Environment on Student Learning. Honors Theses. 2375. Available at: https://scholarworks.wmich.edu/honors_theses/2375. (Accessed 5 May 2016).

Turano, A. A. (2005). The impact of classroom environment on student learning. Theses and Dissertations. Available at: http://rdw.rowan.edu/etd/1089. (Accessed 5 May 2016).

Wubbels, T., Brekelmans, M., \& Hermans, J. (1987). Teacher behaviour; An important aspect of learning environment. In B. J. Fraser (Ed.), The Study of Learning Environments, 13, 10-25). Perth: Curtin University of Technology.

\section{Appendix}

\section{Section A}

This questionnaire is made up of declarations of your chemistry classroom routines and occurrences. How often do the declarations describe these routines?

\section{SCALE:VERY OFTEN - VO}

OFTEN - O

SOMETIMES - ST

\section{SELDOM - SM}

\section{ALMOST NEVER - AN}

\begin{tabular}{|l|l|l|l|l|l|l|}
\hline No. & Statement & VO & O & ST & SM & AN \\
\hline 1. & $\begin{array}{l}\text { Chemistry students form discussion groups with } \\
\text { each other in the chemistry classroom whenever } \\
\text { assignments are given. }\end{array}$ & & & & \\
\hline 2. & $\begin{array}{l}\text { I am not intimidated by anybody when I answer } \\
\text { questions in the Chemistry classroom. }\end{array}$ & & & & & \\
\hline 3. & $\begin{array}{l}\text { I relate in an affable way to all students in the } \\
\text { Chemistry classroom. }\end{array}$ & & & & & \\
\hline 4. & I take pleasure in being in the Chemistry class. & & & & & \\
\hline 5. & $\begin{array}{l}\text { I am capable of studying better with other } \\
\text { students in the Chemistry classroom. }\end{array}$ & & & & \\
\hline
\end{tabular}




\begin{tabular}{|c|c|c|c|c|c|c|}
\hline 6. & $\begin{array}{l}\text { I assist other Chemistry students struggling with } \\
\text { the study of the subject. }\end{array}$ & & & & & \\
\hline 7. & $\begin{array}{l}\text { Other students easily observe my absence in the } \\
\text { Chemistry classroom. }\end{array}$ & & & & & \\
\hline 8. & $\begin{array}{l}\text { When I require a clarification to some } \\
\text { Chemistry problems, I can consult any student } \\
\text { in the Chemistry classroom. }\end{array}$ & & & & & \\
\hline 9. & $\begin{array}{l}\text { The Chemistry teacher constantly guarantees } \\
\text { that I grasp what he/she instructs in class. }\end{array}$ & & & & & \\
\hline 10. & $\begin{array}{l}\text { The Chemistry teacher willingly accepts my } \\
\text { comments on how he/she teaches. }\end{array}$ & & & & & \\
\hline 11. & $\begin{array}{l}\text { During Chemistry lessons the chemistry teacher } \\
\text { readily reviews concepts he/she has taught when } \\
\text { asked by a student. }\end{array}$ & & & & & \\
\hline 12. & $\begin{array}{l}\text { The Chemistry teacher supports me when I am } \\
\text { struggling with the study of chemistry. }\end{array}$ & & & & & \\
\hline 13. & $\begin{array}{l}\text { The Chemistry educator maintains a healthy } \\
\text { student-teacher relationship with me after class. }\end{array}$ & & & & & \\
\hline 14. & $\begin{array}{l}\text { The Chemistry teacher talks excitedly about the } \\
\text { subject which encourages me to study it. }\end{array}$ & & & & & \\
\hline 15. & $\begin{array}{l}\text { The Chemistry teacher motivates me to bring } \\
\text { out the best in me. }\end{array}$ & & & & & \\
\hline No. & Statement & VO & $\mathbf{O}$ & ST & SM & $\mathbf{A N}$ \\
\hline 16. & $\begin{array}{l}\text { The Chemistry educator poses questions to me } \\
\text { ascertain if I grasp the lesson. }\end{array}$ & & & & & \\
\hline 17. & $\begin{array}{l}\text { I participate in class discussions during } \\
\text { Chemistry lessons. }\end{array}$ & & & & & \\
\hline 18. & $\begin{array}{l}\text { I make suggestions during Chemistry class } \\
\text { discussions. }\end{array}$ & & & & & \\
\hline 19. & $\begin{array}{l}\text { I am involved in decision making in the } \\
\text { Chemistry classroom. }\end{array}$ & & & & & \\
\hline 20. & $\begin{array}{l}\text { My contributions during Chemistry class } \\
\text { discussions are accepted by other students. }\end{array}$ & & & & & \\
\hline 21. & $\begin{array}{l}\text { I ask my Chemistry teacher questions when I } \\
\text { have difficulty in understanding. }\end{array}$ & & & & & \\
\hline 22. & $\begin{array}{l}\text { I clarify my contributions to other students (my } \\
\text { classmates) in the chemistry class during our } \\
\text { discussions. }\end{array}$ & & & & & \\
\hline 23. & $\begin{array}{l}\text { Other students support me in the Chemistry } \\
\text { class when I struggle to solve Chemistry } \\
\text { problems. }\end{array}$ & & & & & \\
\hline 24. & $\begin{array}{l}\text { When asked to solve Chemistry problems in } \\
\text { class, am normally asked to give clarifications. }\end{array}$ & & & & & \\
\hline
\end{tabular}




\begin{tabular}{|c|c|c|c|c|c|c|}
\hline 25. & $\begin{array}{l}\text { I cooperate with my classmates when we are } \\
\text { doing our Chemistry assignments. }\end{array}$ & & & & & \\
\hline 26. & $\begin{array}{l}\text { I share my educational materials with my } \\
\text { classmates in the Chemistry classroom. }\end{array}$ & & & & & \\
\hline 27. & $\begin{array}{l}\text { We work as a team when studying in a group } \\
\text { with my classmates in the Chemistry class. }\end{array}$ & & & & & \\
\hline 28. & $\begin{array}{l}\text { There is much competition among us in the } \\
\text { Chemistry class. }\end{array}$ & & & & & \\
\hline 29. & $\begin{array}{l}\text { I understudy my classmates in the Chemistry } \\
\text { class. }\end{array}$ & & & & & \\
\hline 30. & $\begin{array}{l}\text { I enjoy learning with other students in the } \\
\text { Chemistry class. }\end{array}$ & & & & & \\
\hline 31. & $\begin{array}{l}\text { My comments are easily accepted by my } \\
\text { classmates during Chemistry classes. }\end{array}$ & & & & & \\
\hline 32. & $\begin{array}{l}\text { I perform well in Chemistry because my } \\
\text { classmates support with my studies in the } \\
\text { subject. }\end{array}$ & & & & & \\
\hline 33. & $\begin{array}{l}\text { My Chemistry educator gives equal attention to } \\
\text { questions posed by all students in the chemistry } \\
\text { classroom. }\end{array}$ & & & & & \\
\hline 34. & $\begin{array}{l}\text { My Chemistry teacher gives the same amount of } \\
\text { help to all students in the chemistry classroom. }\end{array}$ & & & & & \\
\hline 35. & $\begin{array}{l}\text { All students have the same amount of say in the } \\
\text { Chemistry class. }\end{array}$ & & & & & \\
\hline 36. & $\begin{array}{l}\text { The Chemistry teacher is friendly to me the } \\
\text { same as he/she is to other students in the } \\
\text { Chemistry class. }\end{array}$ & & & & & \\
\hline No. & Statement & VO & $\mathbf{O}$ & ST & $\mathbf{S M}$ & $\mathbf{A N}$ \\
\hline 37. & $\begin{array}{l}\text { I am encouraged by my Chemistry teacher as } \\
\text { other students in the chemistry classroom. }\end{array}$ & & & & & \\
\hline 38. & $\begin{array}{l}\text { The Chemistry teacher believes I can complete a } \\
\text { certain amount of work just like my classmates } \\
\text { in the Chemistry class. }\end{array}$ & & & & & \\
\hline 39. & $\begin{array}{l}\text { My Chemistry teacher gives as much praise to } \\
\text { my work as the work of my classmates. }\end{array}$ & & & & & \\
\hline 40. & $\begin{array}{l}\text { My Chemistry gives me the same opportunity to } \\
\text { answer questions in the class as my classmates. }\end{array}$ & & & & & \\
\hline
\end{tabular}

\section{Section B}

This Attitude Towards Chemistry Questionnaire (ATCQ) is made up of statements on students' attitudes towards Chemistry. Select the statement, which accurately describes your attitude. 
SCALE:STRONGLY AGREE - SA

AGREE - A

UNDECIDED - U

DISAGREE - D

STRONGLY DISAGREE - SD

\begin{tabular}{|c|c|c|c|c|c|c|}
\hline No. & Statement & SA & $\mathbf{A}$ & $\mathbf{U}$ & $\mathbf{D}$ & SD \\
\hline 1. & $\begin{array}{l}\text { It is best to find out why something is true by } \\
\text { checking it from Chemistry textbooks than } \\
\text { being told. }\end{array}$ & & & & & \\
\hline 2. & $\begin{array}{l}\text { The topics covered in Chemistry are not } \\
\text { interesting. }\end{array}$ & & & & & \\
\hline 3. & $\begin{array}{l}\text { There should be more Chemistry lessons every } \\
\text { week. }\end{array}$ & & & & & \\
\hline 4. & $\begin{array}{l}\text { Chemistry is one of the most interesting } \\
\text { science subjects }\end{array}$ & & & & & \\
\hline 5. & I am always prepared for Chemistry lessons. & & & & & \\
\hline 6. & Chemistry lessons are boring. & & & & & \\
\hline 7. & It is important to study Chemistry at school. & & & & & \\
\hline 8. & $\begin{array}{l}\text { I would like to study Chemistry related course } \\
\text { at the highest level of my education. }\end{array}$ & & & & & \\
\hline 9. & Doing well in Chemistry is important to me. & & & & & \\
\hline 10. & I enjoy Chemistry lessons. & & & & & \\
\hline No. & Statement & SA & $\mathbf{A}$ & $\mathbf{U}$ & $\mathbf{D}$ & SD \\
\hline 11. & $\begin{array}{l}\text { I enjoy my specialisation more if there were no } \\
\text { Chemistry lessons. }\end{array}$ & & & & & \\
\hline 12. & $\begin{array}{l}\text { Chemistry is the most difficult of all the } \\
\text { science subjects I have done. }\end{array}$ & & & & & \\
\hline
\end{tabular}

